FAGUTVIKLING

\title{
Veiledning gjør \\ nyutdannede sykepleiere bedre rustet for utfordringer
}

Gjennom gruppeveiledning kan nyutdannede sykepleiere utvikle sin personlige kompetanse. De blir trygge nok til å ta opp utfordrende situasjoner og lærer å sette seg inn i andres perspektiver. 


\section{Inger Marie Tjøstolfsen}

\section{Førstelektor}

Avdeling for helse og velferd, Høgskolen i Østfold

\section{Ruben Grytten}

\section{Spesialsykepleier}

Kompetansesenter for rus og og psykisk helse, Sarpsborg kommune

\section{Gro Hansen}

Sykepleier. Godkjent veileder NSF

Pensjonist

\section{Thor Hoff}

Psykiatrisk sykepleier. Godkjent veileder NSF

Pensjonist

\section{Liv Stanghelle}

Intensivsykepleier. Godkjent veileder NSF

Pensjonist

\section{Ragnhild Ulseth Velund}

Høgskolelektor. Godkjent veileder NSF

Avdeling for helse og velferd, Høgskolen i Østfold

\section{Ruth Våland}

Klinisk spesialist i psykiatrisk sykepleie

Utdanning Kompetanse

Sykepleien 2021109 (87088) (e-87088)

DOI: 10.4220/Sykepleiens.2021.87088

\section{Hovedbudskap}

For nyutdannede sykepleiere er det en utfordring å finne rollen sin i krysningen mellom idealer og realiteter. Denne artikkelen bygger på en studie som viser at veiledning kan bidra til at sykepleiere blir bedre rustet til å møte utfordringer som nyutdannet.

Sykepleiere skal utvikle seg til reflekterte, ansvarlige og selvstendige yrkesut $\varnothing v e r e$. Nyutdannede sykepleiere er gjerne skolert i en tjenestetenkning med vekt på helhetlig omsorg og individualisering, som bare i begrenset grad samsvarer med forventningene i helsetjenesten (1-4). 
Det betyr at det er et gap mellom hvor forberedt sykepleierne er gjennom utdanningen, og utfordringene de møter i praksis $(1,2)$. Kan gruppeveiledning med nyutdannede sykepleiere i helsevesenet bygge en bro og minske gapet?

Profesjonsut $\varnothing$ vere har behov for faglig veiledning jevnlig i løpet av sin yrkeskarriere, og behovet er ekstra stort hos nyutdannede $(5,6)$. Sykepleiere som deltar i individuell veiledning eller gruppeveiledning, opplever større jobbtilfredshet, mindre stress og st $\varnothing$ rre trygghet i yrkesrollen $(5,7)$.

\section{Personlig kompetanse handler om identitet}

Personlig kompetanse handler om vår identitet som person og profesjonell og har betydning for kvaliteten på sykepleierens arbeid $(5,8)$. Danning handler om individets evne til å forme seg selv og beskriver formingen av individets personlighet, oppførsel og moral (9).

Relatert til studien denne artikkelen bygger på, kan utvikling av personlig kompetanse sett som en danningsprosess handle om nyutdannede sykepleieres evne til «å danne seg selv» inn i yrket.

«A danne seg selv» er uttrykt av forfattere fra ulike tider. Ifølge Aristoteles (384 f.Kr.) er det en utvikling av den enkeltes muligheter for å mestre livets oppgaver (10), og Nygård (2007) beskriver det som å konstruere sin selvforståelse som aktør med mulighet til å komme over de vanskelighetene man konfronteres med (11).

Denne studien legger til grunn Skaus (8) forståelse av personlig kompetanse som selvstendighet $\mathrm{i}$ tanke og handling, evne til å lytte til andre og engasjement i det man arbeider med. Veiledning kan fremme danningsprosesser og personlig kompetanse $(5,8,12,13)$.

\section{Veisøkeren utvikler seg gjennom veiledning}

Målet med veiledning er endringsprosessen som skjer hos den som veiledes, eller veis $\varnothing$ keren, og veilederen er katalysatoren i veis $\varnothing$ kerens endringsprosess.

Innholdet i veiledningen er situasjoner som veis $\varnothing$ keren har med fra sin egen yrkespraksis. Veilederen inviterer gruppedeltakerne til å komme med innspill, erfaringer og spørsmål til refleksjon.

Veiledningen kan ende opp med et konkret tiltak for handling eller en mer undersøkende tilnærming som åpner for undring og uferdige tanker (12, 14-16).

\section{«Den nyutdannede sykepleieren utfordres til kritisk å undersøke grunnlaget for sine egne handlinger.»}


Den nyutdannede sykepleieren utfordres til kritisk å unders $ø$ ke grunnlaget for sine egne handlinger (15) og dermed utvikle sin egen praktiske yrkesteori (PYT), se figur 1 (16, s. 25). PYT innebærer håndtering av situasjoner på P1-nivå, begrunnelser for handlingene på P2-nivå og etiske vurderinger på P3-nivå (16).

I gruppeveiledning hjelper medlemmene seg selv og hverandre ved å dele erfaringer, støtte hverandre, gi hverandre motforestillinger og foreslå løsninger (14). Studien legger til grunn en forståelse av veiledning slik vi har beskrevet ovenfor: som en prosess, utvikling av PYT og at veiledningen foregår i gruppe.

I tillegg legger vi til grunn Norsk Sykepleierforbunds forståelse av veiledning: «I veiledning arbeides det med å bidra til, at veis $\varnothing$ ker kan bli bevisst sin egen praksis og eventuelt endre refleksjonsgrunnlag, eller stadfeste eller endre praksis. Faglig veiledning har som siktemål å styrke faglig og personlig kompetanse» (17).

Figur 1. Praktisk yrkesteori (PYT)

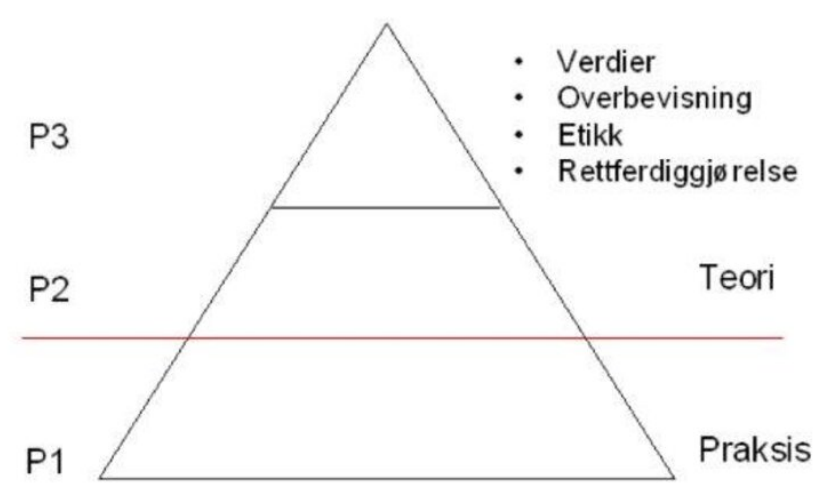

\section{Studiens hensikt}

Studiens hensikt er å beskrive nyutdannede sykepleieres erfaring med gruppeveiledning med søkelys på å utvikle deres personlige kompetanse, som kan gjøre dem bedre rustet til å møte utfordringer. Problemstillingen er: Kan gruppeveiledning fremme utvikling av personlig kompetanse hos nyutdannede sykepleiere? Hvis ja: Hvordan?

\section{Metode}

I studien tilbød vi gruppeveiledning i én time hver 14. dag åtte ganger med en gruppestørrelse på seks-åtte personer på arbeidsstedet. I realiteten møttes tre veiledningsgrupper seks-sju ganger, og én gruppe møttes fire ganger. Vi etablerte grupper med henholdsvis fire, fem og seks deltakere. 


\section{Studiens design}

Fokusgruppeintervju er en egnet metode for å utforske felles erfaringsgrunnlag, og gruppen bør sammensettes så homogent som mulig $(18,22)$. Studien har et kvalitativt design som bygger på fokusgruppeintervju, da vi ønsket å beskrive veis $\varnothing$ kerens felles erfaringer fra veiledningsgruppene.

\section{Rekruttering av informanter}

Inklusjonskriterier for informantene var sykepleiere som var utdannet i løpet av de tre årene forut for studien, det vil si fra og med 2015, og som var veis $\varnothing$ kere i en veiledningsgruppe.

\section{Gjennomføring av fokusgruppeintervju}

Fokusgruppeintervjuene ble gjennomført i desember 2018. Vi gjennomf $\varnothing$ rte to fokusgruppeintervjuer med fire informanter og ett fokusgruppeintervju med tre informanter. Ett intervju gjennomførte vi med én informant.

Informanten hadde samme erfaringsgrunnlag som de øvrige informantene. På denne bakgrunnen valgte vi å bruke datamaterialet fra dette intervjuet, selv om intervjuet ikke tilfredsstilte kravet til antallet deltakere i et fokusgruppeintervju $(18,22)$.

I intervjuene benyttet vi en intervjuguide med tre temaer:

- Oppstart: Kan dere si noe om hvordan dere opplevde etableringen av gruppen?

- Prosess: Kan dere si noe generelt om hvordan veiledningsgruppen ble brukt?

- Resultat: Dersom du skulle si noe om hvilken betydning veiledning kan ha for din utvikling av personlig kompetanse, hva vil det være?

Intervjueren hadde ansvar for å skape det sosiale rommet for samhandling i fokusgruppeintervjuet og styre samtalen mellom deltakerne med utgangspunkt i intervjuguiden (18). Intervjuene startet med en kort introduksjon av rammen for intervjuet, som tid, temaer og at samtalen ble lagret som lydopptak, og deltakerne samtykket til å delta.

Intervjuet startet etter en kort presentasjonsrunde. Deltakerne var kjente for hverandre, men intervjueren møtte gruppen for første gang. Intervjuet varte cirka 30-45 minutter og ble tatt opp på bånd og transkribert.

\section{Analyse}

Vi analyserte de transkriberte intervjuene ved hjelp av systematisk tekstkondensering i fire trinn: å få et helhetsinntrykk, identifisere meningsbærende enheter, abstrahere innholdet i de enkelte meningsbærende enhetene $\mathrm{i}$ underkategorier og samle informasjonen under kategorier (19). 
Først leste alle forfatterne transkripsjonen og analyserte den i temaer. Fortolkningen ble sammenstilt for å få frem et helhetsinntrykk. Så valgte vi ut de meningsbærende enhetene ved at tekst som bærer med seg kunnskap om temaene fra første trinn, ble identifisert.

Underkategorier identifiserte vi ved å abstrahere innholdet i de meningsbærende enhetene, og det abstraherte innholdet i underkategoriene uttrykte vi i kategorier.

\section{Etiske overveielser}

Deltakerne ga informert samtykke etter at de hadde fått skriftlig og muntlig informasjon om anonymisering av personopplysninger, og at de kunne trekke seg fra intervjuet når som helst uten å oppgi årsak til det.

Studien var meldepliktig til Norsk senter for forskningsdata (NSD) og har fătt referansenummer, da data ble innsamlet etter at EUs personvernsordning ble innført i Norge (20).

Deltakerne ble informert skriftlig om sine rettigheter i henhold til personvernforordningen (20) via lederne på arbeidsstedene, som valgte ut deltakerne til veiledningsgruppene. Behandlingen av personopplysninger ble avsluttet 20. desember 2020 i tråd med registreringen i NSD. 
Tabell 1. Eksempel på analyse fra meningsbærende enheter til kategorier

\begin{tabular}{|c|c|c|}
\hline Kategorier & Underkategorier & Meningsbærende enheter (tekstbiter fra intervjuet) \\
\hline 2. Prosess & $\begin{array}{l}\text { 2.1. Trygghet til å } \\
\text { dele utfordrende } \\
\text { situasjoner }\end{array}$ & 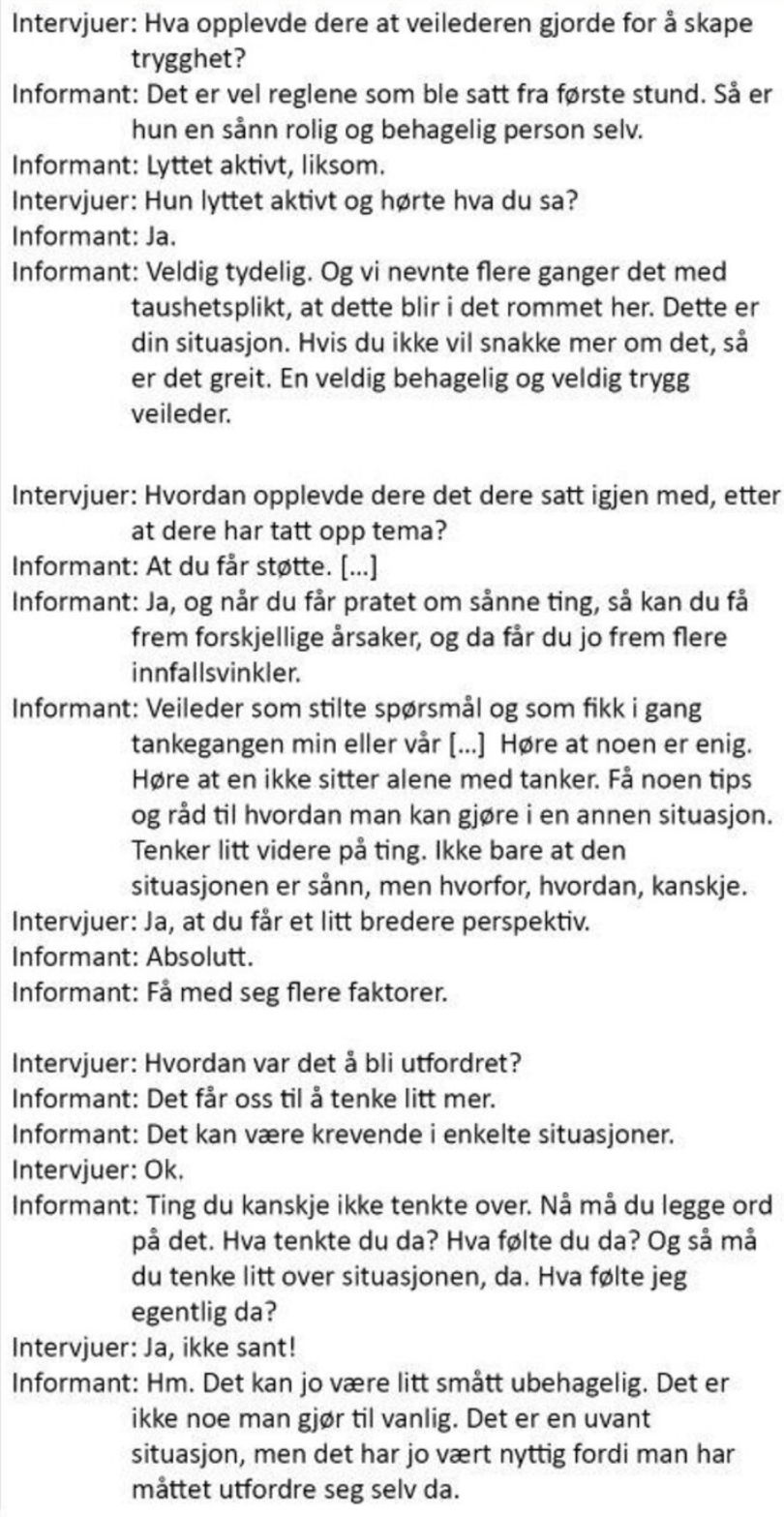 \\
\hline
\end{tabular}

\section{Resultater}

Studiens funn presenteres under tre kategorier, «Etablering av gruppen», «Prosess» og «Utbytte», og tilhørende underkategorier.

\section{Etablering av gruppen}

\section{Forventninger til veiledning}

Informantene uttrykte at de fikk god informasjon i det første møtet i veiledningsgruppen, men konteksten og relasjonen var litt utydelig.

Faktorer av betydning for etablering av gruppen var tydelig hensikt, kontrakt hvor grupperegeler var nedfelt, presentasjon av hvem alle var, og å bli kjent. Noen informanter uttrykte at de trodde veiledningsgruppen skulle inneholde mer undervisning og råd. 


\section{Prosess}

\section{Trygghet til å dele utfordrende situasjoner}

Faktorer av betydning for trygghet i gruppen var kontrakt, at veilederen var aktivt lyttende, at de samme personene møtte opp, å bli kjent med hverandre og å snakke med andre som hadde vært i liknende situasjoner.

\section{Refleksjon}

Viktige bidrag fra gruppen for å fremme refleksjon var tilbakemeldinger, å si hvordan man hadde løst liknende situasjoner, og at alle i gruppen var aktive.

Deltakerne ble utfordret til å svare på spørsmål som «Hva tenkte du da?» og «Hva følte du da?» og uttrykte at det var krevende, men nyttig. Refleksjonen bidro til at de tenkte litt lenger enn det å snakke om situasjonen, og fikk frem flere innfallsvinkler og et bredere perspektiv.

\section{Utbytte}

\section{Selvstendighet i tanke og handling}

Informantene uttrykte at de var blitt tryggere, bedre rustet til å ta opp saker videre, mer bevisst på sine egne tanker og at de hadde vokst som fagpersoner.

\section{Å lytte til andre}

Informantene hadde lyttet til hverandre og viste det ved å stille spørsmål og at de jobbet videre med situasjonen og ikke sporet av.

At alle var nyutdannede og hadde de samme utfordringene, gjorde det veldig interessant for dem å snakke sammen. Med veiledning hadde de blitt flinkere til å snakke sammen om ting som bekymret dem, og de støttet og lyttet til hverandre.

\section{Å vise engasjement}

Informantene uttrykte at det var viktig å ta vare på de nyutdannede. Situasjoner de tok opp i veiledningen, hadde de måttet håndtere så godt de kunne, og det var frustrerende fordi det kunne gå ut over pasienter og pårørende. Intervjueren uttrykte at det kanskje handlet om å bygge opp styrke til å stå i den den reelle hverdagen, noe informantene var enige $\mathrm{i}$.

\section{Diskusjon}

Tre sentrale temaer ved gruppeveiledning for å fremme utvikling av personlig kompetanse hos nyutdannede sykepleiere blir diskutert:

- Å starte veiledningsgrupper

- Å fremme trygghet i gruppen til å kunne ta opp utfordrende situasjoner og fremme refleksjon 
- Å utvikle personlig kompetanse

\section{$\AA$ starte veiledningsgrupper}

Studien viste at veis $\varnothing$ kerne og veilederen har behov for en felles forståelse av hva som skal skje i veiledningen.

Informantene ga uttrykk for at de kunne blitt informert tydeligere om hvordan gruppeveiledningen skulle gjennomføres. Noen informanter trodde veiledningsgruppen skulle inneholde mer undervisning og råd.

\section{«Å veilede andre sykepleiere bør være en integrert og nødvendig del av arbeidet som sykepleier.»}

Ved å informere om veiledningens hensikt og hvordan gruppeveiledning kan gjennomføres, sikrer veilederen seg at utgangspunktet blir så godt som mulig (21).

I profesjonsveiledning er det av betydning at veilederen har hovedvekten på en prosessorientert rolle som legger til rette for at deltakerne selv finner frem til forståelse og handlingsmuligheter (21).

$\AA$ veilede andre sykepleiere bør være en integrert og nødvendig del av arbeidet som sykepleier som er støttet og forankret hos ledelsen på arbeidsstedet $(5,22)$.

I studien ga ledelsen skriftlig samtykke til å delta i prosjektet og rekrutterte veis $\varnothing$ kere, og med det formidlet de at de $\varnothing$ nsket å tilrettelegge for veiledningsgrupper.

\section{A fremme trygghet i gruppen til å kunne ta opp utfordrende situasjoner og fremme refleksjon}

Studien viste at veilederen kan fremme trygge veis $\varnothing$ kere som reflekterer over utfordrende situasjoner.

$\AA$ ha en kontrakt hvor grupperegler som aktuelle temaer, taushetsplikt og fravær var nedfelt, og at veilederen var aktivt lyttende, bidro til at informantene følte seg trygge nok til å ta opp utfordrende situasjoner i studien.

Aktiv lytting innebærer å formidle bekreftelse og anerkjennelse til det veisøkeren

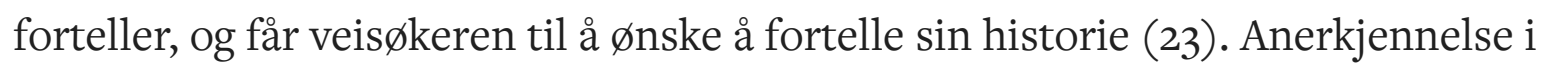
veiledning kan bidra til at veisøkeren kommer i kontakt med sine egne forutsetninger for samhandling. Egen sårbarhet kan bli en ressurs når den møtes med anerkjennelse, som bidrar til trygghet og refleksjon (24). 
Ved å være tilbakeholden, oppmerksomt lyttende og la veisøkeren få snakke ferdig kan veilederen bidra til å gi veisøkeren et rom å handle og vokse i (25).

I studien uttrykte informantene at å bli i utfordret av veilederen til å beskrive tanker og følelser knyttet til erfaringer, fremmet refleksjon og var nyttig, men kunne også være krevende. Veilederen må sette søkelys på hele mennesket $\mathrm{i}$ veiledningen: veisøkerens tanker, følelser, fornuft, kropp og handlinger $(14,24)$.

\section{«Veilederen må sette søkelys på hele mennesket $\mathrm{i}$ veiledningen: veisøkerens tanker, følelser, fornuft, kropp og handlinger.»}

Refleksjon kan forstås som å vende tilbake til en erfaring og kritisk unders $\varnothing$ ke grunnlaget for sine egne handlinger (14-16). Veilederens oppgave blir å bidra til at situasjonen blir tatt opp i veiledningen på en slik måte at veisøkerens PYT blir tydelig for ham selv.

I gruppeveiledning kan veilederen invitere gruppen til å stille spørsmål til oppklaring, til å støtte, utfordre og reflektere og til å bruke kort og fantasireiser (5, 14, 15). Veilederne i studien brukte slike verktøy.

De fikk også støtte av at det reflekterende teamet (som besto av gruppedeltakerne unntatt veilederen og veis $\varnothing$ keren) samtalte seg imellom om hva de hadde sett, hørt og observert, og hva de trodde dette handlet om.

Gruppens bidrag og refleksjon bidro til at informantene fikk frem et bredere perspektiv. Perspektivering skal bidra til å åpne opp og se saken på nye måter og reflektere kritisk over handlinger og tenkning som tas for gitt $(15,16)$.

\section{Å utvikle personlig kompetanse}

Informantene uttrykte at de ble mer bevisst på sine egne tanker og bedre rustet til å ta opp saker videre etter å ha reflektert over situasjoner i veiledningen. Personlig kompetanse handler om å reflektere over og lære av våre handlinger og kan komme til uttrykk som selvstendighet i tanker og handling (8).

Informantene lyttet til hverandre og var frustrert over at situasjoner kunne gå ut over pasienter og pårørende. Personlig kompetanse kan komme til uttrykk som evne til å lytte til andre og være engasjert i det man arbeider med (8).

Det kan også synes som at gruppeveiledning kan bidra til utvikling av personlig kompetanse gjennom selvstendighet i tanker og handling, å lytte til andre og å vise engasjement i det man arbeider med. 


\section{Avslutning}

Veilederen i gruppeveiledning av nyutdannede sykepleiere kan fremme utvikling av personlig kompetanse og gjøre dem bedre rustet til å møte utfordringer.

Veilederen kan bidra til en felles forståelse av veiledningens hensikt og hvordan gruppeveiledningen kan gjennomføres, skape trygghet til å kunne ta opp utfordrende situasjoner, fremme refleksjon ved å bruke ulike veiledningsverktøy og invitere gruppen til å bidra i prosessen.

Veilederen kan bidra til at veisøkerne blir aktive i sin egen tenkning, setter seg inn i andres perspektiv og bruker sin stemme i dialogen. I tillegg kan veilederen sørge for at gruppeveiledningen er forankret i ledelsen, som sikrer kontinuitet i gruppedeltakelsen ved prioritering og tilrettelegging.

\section{Referanser}

1. Orvik A. Organisatorisk kompetanse. Innføring i profesjonskunnskap og klinisk ledelse. 2. utg. Oslo: Cappelen Damm Akademisk; 2015.

2. Neal-Boylan L. The nurse's reality gap: overcoming barriers between academic achievement and clinical success. Indianapolis: SIGMA Theta Tau International, Center for Nursing Press; 2013.

3. Forskrift 15. mars $2019 \mathrm{nr} .412 \mathrm{om}$ nasjonal retningslinje for sykepleierutdanning. Oslo: Kunnskapsdepartementet; 2019. Tilgjengelig fra: https://lovdata.no/dokument/SF/forskrift/2O19-03-15-412 (nedlastet 26.10.2021).

4. Forskrift om felles rammeplan for helse- og sosialfagutdanninger. Oslo: Kunnskapsdepartementet; 2017. Tilgjengelig fra: https://lovdata.no/dokument/SF/forskrift/2017-09-06-1353 (nedlastet 26.10.2021).

5. Vråle GB. Veiledning når det røyner på. 1. utg. Oslo: Gyldendal Akademisk; 2015 .

6. Norsk Sykepleierforbund. Øke kvaliteten i utdanningene. Oslo: Norsk Sykepleierforbund; u.å. Tilgjengelig fra: https://www.nsf.no/vart-politiskearbeid/oke-kvaliteten-i-utdanningene (nedlastet 23.04.2021).

7. Dyess S, Parker CG. Transition support for the newly licensed nurse: a program that made a difference. Journal of Nursing Management. 2012;20(5):61523. DOI: $10.1111 / \mathrm{j} \cdot 1365-2834.2012 .01330 . \mathrm{x}$

8. Skau GM. Gode fagfolk vokser. Personlig kompetanse i arbeid med mennesker. 5. utg. Oslo: Cappelen Damm Akademisk; 2017. 
9. Hogstad KH. Dannelse. Oslo: Store norske leksikon; 2009. Tilgjengelig fra: https://snl.no/dannelse (nedlastet 23.04.2021).

10. Stigen A. Tenkningens historie 1. Oldtiden, middelalderen, nyere tid inntil vitenskapen på 1600-tallet. 3. utg. Oslo: Ad Notam Gyldendal; 1983.

11. Nygård R. Aktør eller brikke. Søkelys på menneskets selvforståelse. 2. utg. Oslo: Cappelen Damm; 2007.

12. Bjerkholt E. Profesjonsveilending. Fra praktisk virksomhet til teoretiske felt. 1. utg. Oslo: Cappelen Damm Akademisk; 2017.

13. Lepp M. Handledning för professionell utveckling. I: Lepp M, Leksell J, red. Vårdpedagogik. Vårdens kärnkompetenser från ett pedagogisk perspektiv. 1. utg. Stockholm: Liber AB; 2017. s. 349-69.

14. Tveiten S. Veiledning - mer enn ord. 5. utg. Bergen: Fagbokforlaget; 2019.

15. Lauvås P, Lycke KH, Handal G. Kollegaveiledning med kritiske venner. 4. utg. Oslo: Cappelen Damm; 2016.

16. Lauvås P, Handal G. Veiledning og praktisk yrkesteori. 3. utg. Oslo: Cappelen Damm Akademisk; 2014.

17. Norsk Sykepleierforbunds faggruppe for veiledere. Veilederen. Om faglig veiledning i sykepleie. Oslo: Norsk Sykepleierforbund. Tilgjengelig fra: https://www.digiblad.no/nsf/veilederen/files/assets/basic-html/page-4.html (nedlastet 10.05.2021).

18. Malterud K. Fokusgrupper som forskningsmetode for medisin og helsefag. 1. utg. Oslo: Universitetsforlaget; 2012.

19. Malterud K. Kvalitative forskningsmetoder for medisin og helsefag. 4. utg. Oslo: Universitetsforlaget; 2017.

20. Lov 15. juni $2018 \mathrm{nr} .38$ om behandling av personopplysninger (personopplysningsloven). Tilgjengelig fra: https://lovdata.no/dokument/NL/lov/2018-06-15-38 (nedlastet 10.05.2021).

21. Ulleberg I. Kommunikasjon og veiledning: en innføring i Gregory Batesons kommunikasjonsteori - med historier fra veiledningspraksis. 2. utg. Oslo: Universitetsforlaget; 2014. 
22. Kristoffersen NJ. Sykepleie - kunnskapsgrunnlag og kompetanseutvikling. I: Kristoffersen NJ, Nortvedt F, Skaug E-A, Grimsbø GH, red. Grunnleggende sykepleie. Sykepleie - fag og funksjon. Oslo: Gyldendal Akademisk; 2016. Bind 1, s. 139-92.

23. Eide H, Eide T. Kommunikasjon i relasjoner. 3. utg. Oslo: Gyldendal Akademisk; 2017.

24. Andreassen AJ, Magnussen IL. Lærer anerkjennende veiledning. Sykepleien. 2015;(3):68-71. DOI: 10.4220/Sykepleiens.2015.53373

25. Kristiansen A. Hva hører du når du lytter? Hvem blir du når du svarer? I: Eide SB, Grelland HH, Kristiansen A, Sævareid HI, Aasland DG, red. Til den andres beste. En bok om veiledningens etikk. 2. utg. Oslo: Gyldendal Akademisk; 2020. s. 59-72. 